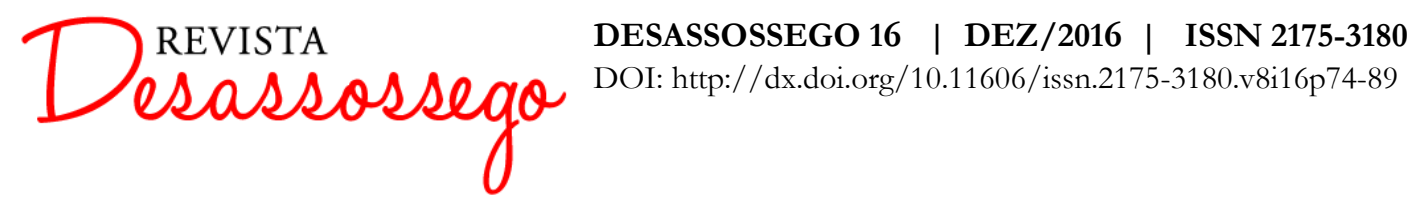

\title{
FALA, FALTA, FALHA: O ISTO DE MANUEL ANTÓNIO PINA
}

Aline Duque Erthal ${ }^{1}$

\begin{abstract}
Resumo: Este artigo investiga de que maneira o descompasso entre sujeito, mundo e poesia constrói, em Manuel António Pina, o conceito de falha, que se encontra intrinsecamente ligado à noção de falta e ao exercício da fala. A partir da observação desse trinômio falha/falta/fala, que atravessa e sustenta a obra do poeta, chegamos a outra ideia-chave - a de "isto" -, e concluímos que a ênfase nessa poesia está muito mais na relação (o salto da linguagem, que permeia toda a frase sem se condensar em uma só palavra) do que em um ou outro significante.
\end{abstract}

Palavras-chave: Manuel António Pina; Poesia portuguesa; Contemporaneidade.

\section{SPEECH, LACK, FAULT: THE NOUN IT [OR THIS] IN MANUEL ANTÓNIO PINA}

Abstract: This paper investigates how the gap between subject, world and poet builds, in Manuel António Pina's work, the concept of fault, which is linked to the notion of lack and the exercise of speech. From the observation of the triad fault/lack/speech, which passes through and supports the work of the poet, we come to another key idea - the noun "isto", wich means "it" or "this" and conclude that the emphasis of this poetry is much more in the relationship than in one specific significant.

Keywords: Manuel António Pina; Portuguese poetry; Contemporaneity.

"É o que falta que fala / do lugar do exílio / do sentido e da falta de sentido." (PINA, 2013, p. 272). Estes versos, do livro Nenbuma palavra e nenbuma lembrança (publicado em 1999), condensam um jogo que é das principais forças motrizes de toda a poética de Manuel António Pina. O binômio fala/falta atravessa momentos os mais diversos de sua obra e inscreve nos versos, mesmo quando sem escrevê-lo, um terceiro parônimo, a vazar (nas acepções de moldar, derramar e escavar do verbo) e sustentar os demais: a falha. Conceito que vem se mostrando chave nas pesquisas para minha tese de doutorado - que propõe e desenvolve a noção de função deserto em obras específicas de Carlos de Oliveira, Luis Miguel Nava e António Ramos $\operatorname{Rosa}^{2}$-, a falha mostra-se não apenas motivo e resultado daquela falta que é um dos principais temas da modernidade poética portuguesa, mas também, e sobretudo, a potência de sua fala.

Neste artigo, dando sobretudo voz ao poeta (propositalmente, numerosas e, por vezes, longas serão as citações), pretendemos observar como a falha se constrói, na obra de

\footnotetext{
1 Doutoranda em Literatura Portuguesa com bolsa Capes na Universidade Federal Fluminense (UFF). Niterói, Brasil. alinerthal@gmail.com

2 Cf. ERTHAL, Aline Duque. "Deserto excessivo: povoamento de multiplicidades". Revista Texto Poético (ANPOLL), vol. 16, 10 sem 2014. p. 9-30. Disponível em: http://www.revistatextopoetico.com.br/index.php/rtp/article/view/206/229
} 


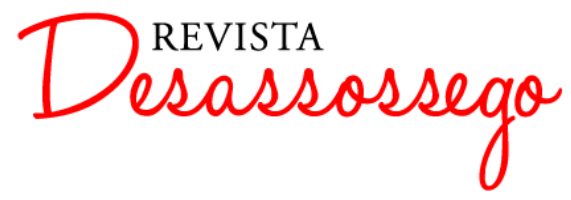

DESASSOSSEGO 16 | DEZ/2016 | ISSN 2175-3180

DOI: http://dx.doi.org/10.11606/issn.2175-3180.v8i16p74-89

Pina, a partir do irremediável descompasso entre sujeito, mundo e poesia, e também de que maneira a falha/falta/fala que se escreve constitui, a um só tempo, escassez e excesso, perda e multiplicidade.

Carlos Drummond de Andrade, no seu primeiro livro, de 1930, já escrevia: "Impossível escrever um poema a essa altura da evolução da humanidade." (ANDRADE, 2001, p. 83). O caráter tardio de toda poesia moderna (que, no entanto, continua se fazendo - Drummond termina o mesmo texto dizendo: "Desconfio que escrevi um poema") é um dos topoi privilegiados pela escrita em língua portuguesa, inscrevendo nos versos a tensão entre já não (que originalidade ainda seria possível? Como escrever poesia em um mundo mercantilizado?) e ainda não (a eterna fugacidade da palavra poética, a inelutável insuficiência e inapropriação da linguagem, a exigência permanente de uma língua nova). Paulo Henriques Britto põe em claros termos a questão:

2

Chegamos tarde, é claro. Como todos.

Chegamos tarde, e nosso tempo é pouco,

o tempo exato de dizer: é tarde.

Todas as sílabas imagináveis soaram. Nada ficou por cantar, nem mesmo o não-ter-mais-o-que-cantar,

o não-poder-cantar, já tão cantado que se estiolou no infinito banal de espelhos frente a frente a refletir-se,

restando da palavra só o resumo da pálida intenção, indisfarçada, de não dizer, dizendo, coisa alguma.

$[\cdots]$

5

Toda palavra já foi dita. Isso é

sabido. E há que ser dita outra vez.

E outra. E cada vez é outra. E a mesma.

Nenhum de nós vai reinventar a roda.

E no entanto cada um a re-

inventa, para si. E roda. E canta.

Chegamos muito tarde, e não provamos

o doce absinto e ópio dos começos.

E no entanto, chegada a nossa vez,

recomeçamos. Palavras tardias, 
mas com a vertiginosa lucidez -

o ácido saber de nossos dias. (BRITTO, 2007, p. 87)

Em Portugal, a interrogação do tempo da poesia ganha o sabor particular de um passado excessivo. Tradição que é travo e tema, dando o mote para interrogações, em contexto mais amplo, acerca de um próprio poético moderno: o incômodo escrever que faz dos obstáculos sua condição; que se erige justamente sobre sua falha (pensamos em Nava: “Abro na página um buraco onde alicerço a casa, as letras vêm às janelas”. NAVA, 2002, p. 55). Essa construção é e precisa ser instável em seu (porque específico embora indeterminável) lugar e seu tempo. Manuel António Pina di-lo muito melhor do que nós, no poema "Neste preciso tempo, neste preciso lugar":

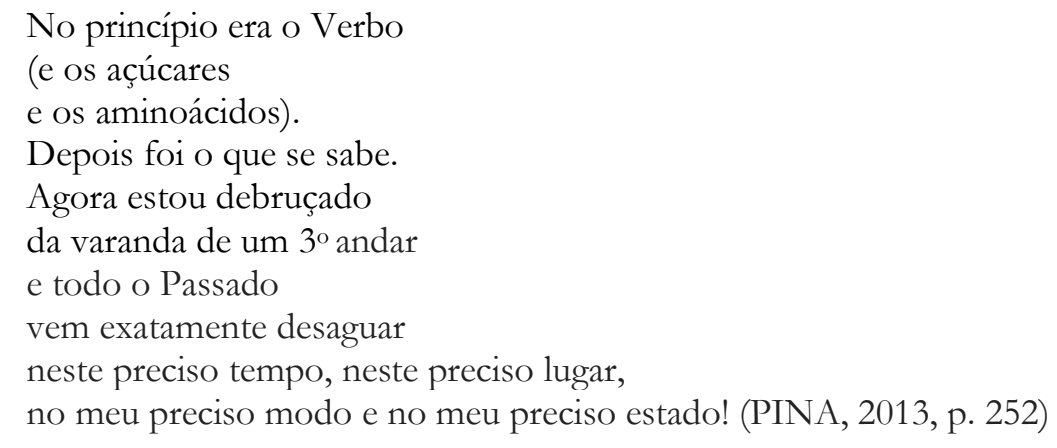

Ironia é arma que vem bem a calhar neste trabalho difícil que é o da poesia moderna: no indefinido, definir-se; achar um entre (entrada e intervalo) na indiferença; demarcar no inespecífico sua propriedade. O poema segue:

Todavia em vez de metafísica

ou de biologia

dá-me para a mais inespecífica

forma de melancolia:

poesia nem por isso lírica

nem por isso provavelmente poesia.

Pois que faria eu com tanto Passado

senão passar-lhe ao lado,

deitando-lhe o enviesado

olhar da ironia?

Por onde vens, Passado, pelo vivido ou pelo sonhado?

Que parte de ti me pertence,

a que se lembra ou a que esquece?

Lá em baixo, na rua, passa para sempre 


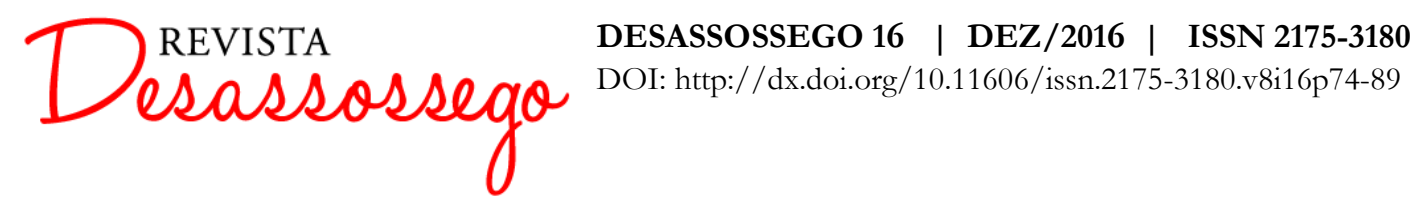

gente indefinidamente presente, entrando na minha vida por uma porta de saída que dá já para a memória. Também eu (isto) não tenho história senão a de uma ausência entre indiferença e indiferença. (PINA, 2013, p. 252-253)

Livrar-se de tantos "tanto" (literatura ${ }^{3}$, memória ${ }^{4}$, silêncio ${ }^{5}$ ) não passa, em Pina, pela recusa do passado - também isso já se fez (rima, maiúscula, ponto e estrofe estão no poema para mostrar com graça que mesmo essa pretensão seria antiquada a esta altura do campeonato). Trata-se, é esta a nossa hipótese, de convocar à página todos os tempos e lugares, não para que eles se cruzem em um ponto no qual algum sujeito ou chave poética se encontre, mas para que todos os tempos e lugares corram paralelos, e entre eles, na mesma página que eles, mas jamais em um deles, se façam a poesia e a subjetividade poética. Mas aí chegaremos daqui a pouco.

Primeiro, atente-se para uma sequência de gestos movimentada nos poemas que abrem o volume intitulado Os livros. Ela pode se resumir assim: expressão do desejo de aceder a um antes; manifestação da consciência de que, para aceder a um antes, será necessário partir do depois; interrogação acerca do modo como empreender esse projeto. Fragmentos desse percurso:

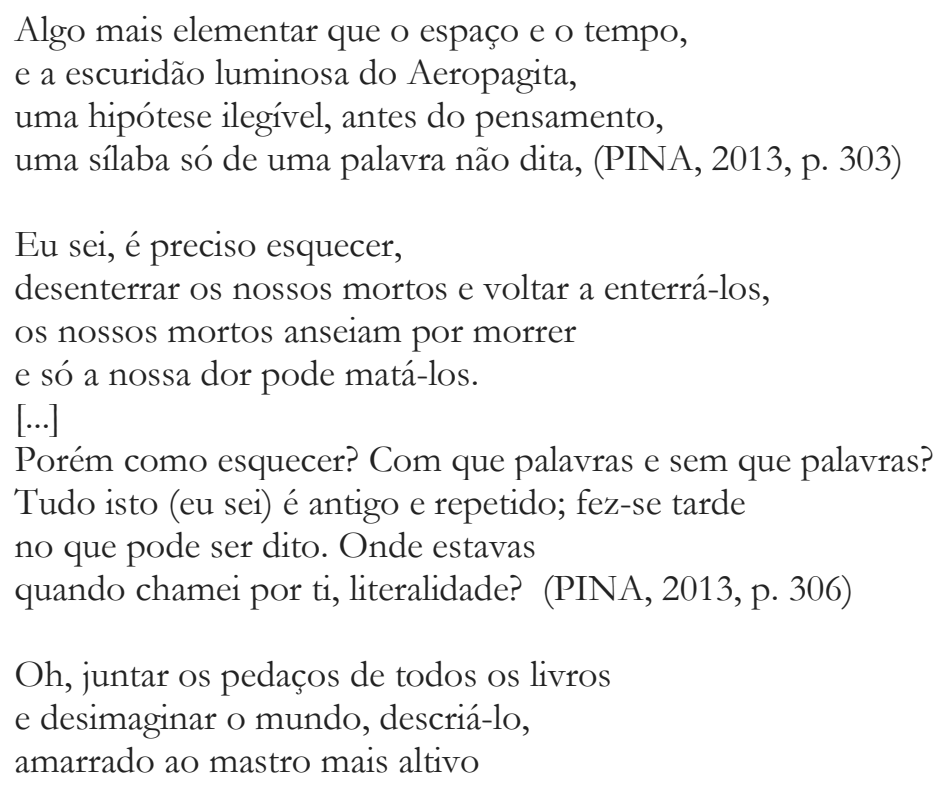

Algo mais elementar que o espaço e o tempo, e a escuridão luminosa do Aeropagita, uma hipótese ilegível, antes do pensamento, uma sílaba só de uma palavra não dita, (PINA, 2013, p. 303)

Eu sei, é preciso esquecer, desenterrar os nossos mortos e voltar a enterrá-los, os nossos mortos anseiam por morrer e só a nossa dor pode matá-los.

$[\ldots]$ Porém como esquecer? Com que palavras e sem que palavras? Tudo isto (eu sei) é antigo e repetido; fez-se tarde no que pode ser dito. Onde estavas quando chamei por ti, literalidade? (PINA, 2013, p. 306)

Oh, juntar os pedaços de todos os livros e desimaginar o mundo, descriá-lo, amarrado ao mastro mais altivo

\footnotetext{
3 "Vai, pois, poema, procura / a voz literal / que desocultamente fala / sob tanta literatura."; "sob tanto passado insepulto” (PINA, 2013, p. 309).

4 Tanta memória!" (PINA, 2013, p. 306).

5 "Tanto silêncio" é justamente o título de um poema (p. 316).
} 


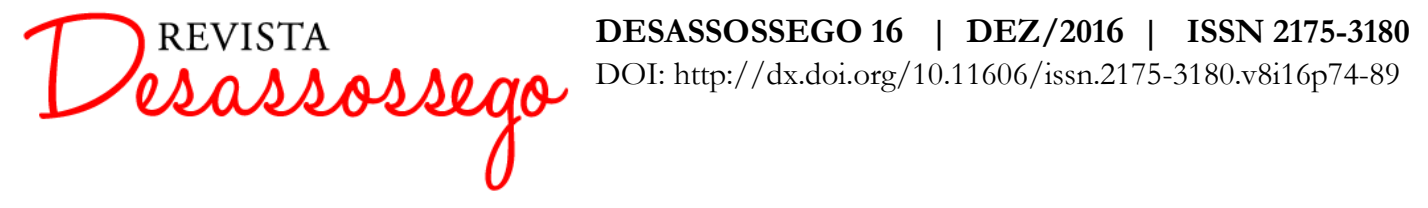

do passado! Mas onde encontrar um passado? (PINA, 2013, p. 307)

Tivemos um passado mas também ele não nos pertenceu, lemo-lo, ou ouvimo-lo a

outros mais densos que nós.

Aonde regressamos então?

[...] (PINA, 2013, p. 314)

A exigência de um desaprender anda longe de ser novidade - e assume-o o próprio poema - em literatura portuguesa: de imediato, basta que se pense em Alberto Caeiro e seu desejo de um olhar originário, despido de cultura, que tantas lições foi colher ao zenbudismo; e em poetas posteriores, como António Ramos Rosa, que continuam a movimentar a problemática. A dificuldade dessa empresa também atravessa a produção literária e filosófica (inocência e experiência, em Blake, segunda inocência, em Nietzsche): como recuperar, com olhos adultos, a faísca da novidade da infância?

$\mathrm{Na}$ busca por respostas, o tema do(s) e a performance de regresso(s) perpassam a obra de Pina. Desde logo, no entanto, e cada vez mais, torna-se claro: é preciso abandonar a acepção (ocidental) mais corriqueira de tempo - e, consequentemente, de lugar. Morte e infância, por exemplo: ambas igualmente podem se identificar com esse "retorno" almejado, que corresponderia tanto à habitação anterior da "uma hipótese ilegível, antes do pensamento" (p. 303) quanto a lugares enfim reais (acedidos depois de se esquecer).

Um tempo houve em que,

De tão próximo, quase podias ouvir

O silêncio do mundo pulsando

Onde também tu eras mundo, coisa pulsante.

Extinguiu-se esse canto

Não na morte

Mas na vida excluída

Da clarividência da infância

[...]

A música, só voltarás a escutá-la

Numa noite lívida,

Uma noite mais vulnerável do que todas

(o presente desvanecendo-se, o passado cada vez mais lento)

Um pouco antes de adormeceres

Sob escombros. (PINA, 2013, p. 360)

A questão é bastante pessoana e contamina boa parte da produção poética que lhe seria posterior - pensemos por exemplo em Ruy Belo, uma das maiores referências 
assumidas por Pina em sua escrita ${ }^{6}$. Em entrevista a Luís Miguel Queirós publicada em 2011 no jornal Público e, em versão mais completa, no portal do Instituto de Literatura Comparada Margarida Losa, Pina diz:

A infância é algo que só se tem quando se perde, porque as crianças estão perto de mais da infância para se aperceberem dela. Como em outras poesias, na minha a infância -a palavra "infância" e a ideia de infância mais do que a concreta memória de uma infância - é, julgo eu, a melancolia da "primeiridão", de um tempo mítico em que olhámos o mundo e a nós próprios pela primeira vez, com olhos inocentes de palavras e de memória, isto é, "não embaciados de nenhuma palavra/ e nenhuma lembrança". Não é a inocência da criança, que é uma inocência inocente, mas uma nietzschiana "segunda e mais perigosa inocência", uma inocência que se sabe inocente, ou então apenas uma espécie de vontade de inocência. (2015)

A "melancolia da "primeiridão" é, portanto, mais do que lamento por um passado irrecuperável. Pois a inocência que se quer é aquela "mais perigosa" . Deslocada, ela não se localiza no passado, no presente nem no futuro linear: "Talvez percorramos uma rota circular / através da curvatura do espaço e do tempo / onde haveremos de nos reencontrar; / será que então de alguma forma nos reconheceremos? (PINA, 2013, p. 321). Os diferentes tempos são chamados ao poema, convivem, mas não chegam a se cruzar em um ponto onde se encontra, teria se encontrado ou vai se encontrar o sujeito:

\author{
Brincarei ainda na infância \\ Lembrando-me agora? \\ E que recordação \\ Me pensa a esta hora? \\ O que sou passou \\ Pela minha existência, \\ Tenho uma presença \\ Mas já lá não estou: \\ Sou também lembrança \\ De alguém em algum sítio, \\ Onde não alcança \\ O que, lembrado, sinto. \\ E aí repousa já
}

\footnotetext{
${ }^{6}$ Em Belo, a infância é "coisa talvez que só por havê-la deixado alguma coisa significa" (BELO, 2009, p. 532). Outros versos: "as crianças todas as crianças quando são crianças / e só mais tarde sabem tê-lo sido e ter perdido / a insciente ciência de sabê-lo ser" (p. 465); "a infância é uma insignificância eu sei / e apenas por a termos perdido a amamos tanto" (p. 670); "envelheci eu sei e só ganhei o que perdi. Sou de uma adulta idade" (p. 421); "Senhor que a minha vida seja permitir a infância / embora nunca mais eu saiba como ela se diz" (p. 284).

${ }^{7}$ A referência a Nietzsche está também neste título de poema: "Uma segunda e mais perigosa inocência" (PINA, 2013, p. 68).
} 


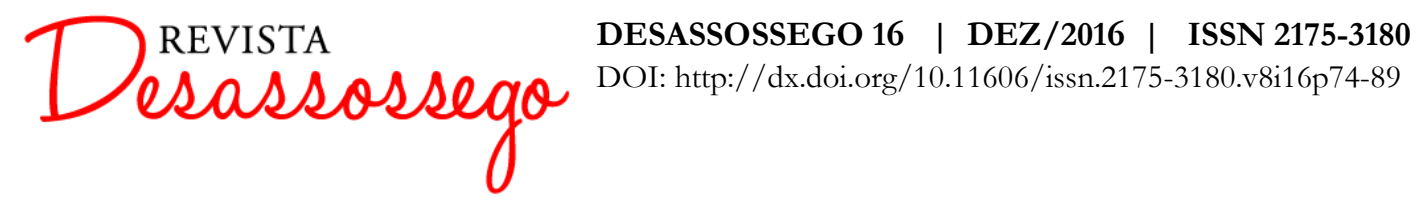

Tornado esquecimento

Um dia que virá

Há muito, muito tempo. (PINA, 2013, p. 222)

Trata-se, portanto, da ideia não apenas de uma origem vedada ou anseio pela morte, mas da impossibilidade de um instante plenamente realizável. E é sendo justo com essa impossibilidade que o poeta pode realizar alguma coisa. Qualquer encontro só se torna possível na perda; "no inverno é que o verão existe verdadeiramente" (Ruy Belo, "Da poesia que posso", 2009, p. 339). ${ }^{8}$ Em diversos poemas de Pina, lê-se o descompasso entre vida e morte. É em um entre que essa poesia se localiza, mas esse entre é "fora das juntas": ele não se encontra no caminho que separa um começo e um fim habituais (já tínhamos alertado que o abandono das noções tradicionais de tempo e de lugar seria uma exigência dessa escrita). A fala, aqui, é a fala de um homem já morto - embora ainda não. De novo, vem Ruy Belo à lembrança, com seu "Vat 69" - a bem dizer, toda uma tradição marulha

\footnotetext{
${ }^{8}$ Em Belo, entra no jogo a faísca insustentável da novidade ("através das profanas novidades de palavras", 2009, p. 140), que só o é naquele preciso instante da mais efêmera duração. Esse instante irrecuperável é retomado em outros poemas do livro, como "Imaginatio locorum" ("Talvez primeiros passos olhos limpos / escolas jogos coisas novamente novas haja ainda" e "- ah! poder eu molhar os meus actuais pés pela primeira vez”, p. 144) e "O último inimigo” (“ó alegria inerente ao começo das coisas”, p. 165).

${ }^{9}$ Embora custe amputar poemas, rememoramos alguns fragmentos:

Era depois da morte herberto helder

Ia fazer três anos que morrêramos

três anos dia a dia descontados no relógio

da torre que de sombra nos cobriu a infância:

[...]

Era a seguir à morte meu poeta

era na meninice havia festa e na sala da entrada

pensávamos na morte — nunca mais - pela primeira vez

$[\ldots]$

Era depois da morte sobre a plana infância

o primeiro natal o cheiro do jornal

lido na adega ou na casa do forno

sentados pensativos sobre a terra húmida

Era na infância o sol caía enquanto água corria

entre os pés de feijão e os buracos de toupeiras

calcados prontamente pelas botas

soprava o vento e vinha a moinha da eira

o cão comia o bolo e morria debaixo da figueira

e teria sepultura com enterro e cruz e muitas flores

[..]

Era depois da morte ou era antes da morte?

Mas haveria a morte verdadeiramente?

Lia o paulo e virgínia chorava e perguntava

se tudo aquilo tinha acontecido

Era o meu pai era esse sonhador incorrigível

sem nunca mais saber que havia de fazer dos dias

Eram as folhas novas eram os perdigotos

saídos não há muito ainda da casca
} 


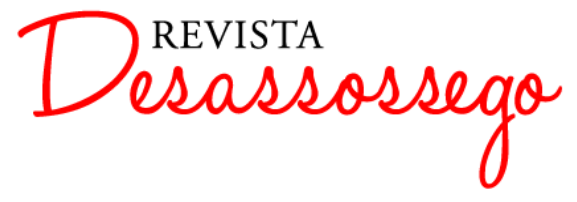

DESASSOSSEGO 16 | DEZ/2016 | ISSN 2175-3180

DOI: http://dx.doi.org/10.11606/issn.2175-3180.v8i16p74-89

das profundezas desses versos, a culminar na desinstalação do sujeito lírico e do seu fazer poético, que podem até, em alguns momentos, ser atravessados ou por uma linha temporal ou por uma linha espacial, mas jamais encontrarão um seu lugar e um seu tempo. Sujeito e poesia estão sempre em movimento, mas em movimento no mesmo entre (não lugar e não tempo). Daí que outra noção frequente em Pina, a da imobilidade, também precise ser entendida de forma diferente da habitual. O movimento existe, mas não no sentido de deslocamento espaço-temporal de um ponto x para um ponto y. $\mathrm{O}$ que significa que algo acontece, mas esse acontecimento não pertence nem a um tempo nem a um lugar. Versos de dois poemas (o grifo no primeiro deles é do próprio poeta):

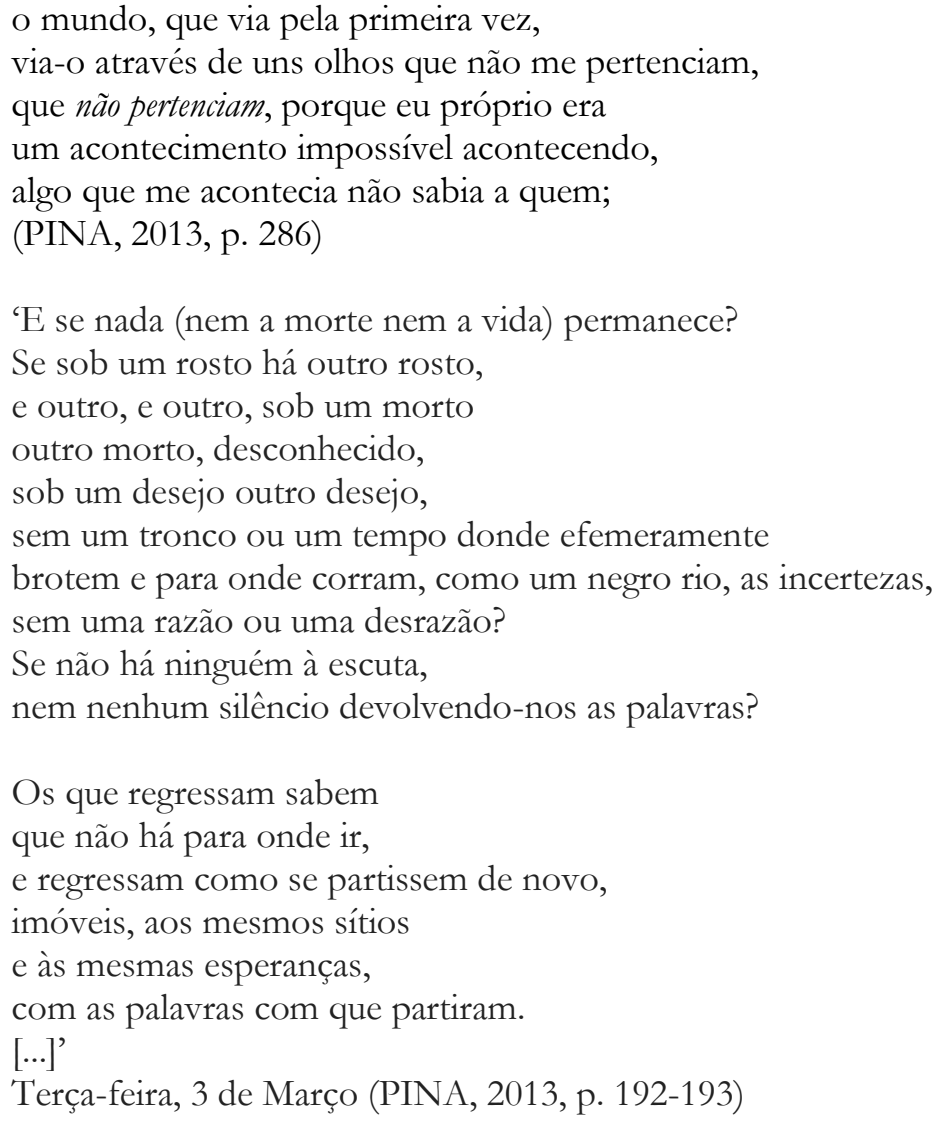

"Imobilidade" não tem a ver, portanto, com pertencimento ou permanência. É signo para o estado de expulsão do movimento ordinário do mundo e das caixas em que se costumam guardar as coisas. "Os meus sentidos expulsaram-me de mim, / desamarraramme de mim e agora / só me lembro pelo lado de fora." (PINA, 2013, p. 287). O que aciona essa expulsão é a escrita poética, fato que carrega em si uma ironia: é imobilizando as 
palavras no papel que se permite que elas se movam fora do tempo e fora do espaço, ou seja, que elas tenham essa imobilidade tal de que nos fala o poeta - "só o que infinitamente pára se move, fugindo," (PINA, 2013, p. 81) ${ }^{10}$. Tomo emprestados alguns destaques feitos por Tatiana Salem Levy, em seu livro $A$ experiência do fora, dada a proximidade que o conceito de fora, tal como analisado por ela em Blanchot, Foucault e Deleuze, tem com o tema de minhas pesquisas. A certa altura, Tatiana aproxima duas citações de Blanchot, e

10 Ocorre-nos agora Eliot em "Burnt Norton", de Os quatro quartetos:

No ponto morto do mundo em rotação. Nem came nem espírito;

Nem de nem para; no ponto morto, aí está a dança,

Mas nem paragem nem movimento. E não se chame a isso fixidez,

Onde o passado e o futuro se reúnem. Nem movimento de nem para,

Nem ascensão nem declínio. Se não fosse o ponto, o ponto morto,

Não haveria dança, e há só a dança.

Eu apenas posso dizer, estivemos ali: mas não posso dizer onde.

E não posso dizer por quanto tempo, pois seria situar isso no tempo.

$[.$.

O tempo passado e o tempo futuro

Apenas concedem um pouco de consciência.

Estar consciente é não estar no tempo

$[\ldots]$

As palavras movem-se, a música move-se

Apenas no tempo; mas o que apenas vive

Apenas pode morrer. As palavras, depois de ditas,

Alcançam o silêncio. Apenas pela forma, pelo molde,

Podem as palavras ou a música alcançar

O repouso, tal como uma jarra chinesa ainda

Se move perpetuamente no seu repouso.

Não o repouso do violino, enquanto a nota dura,

Não isso apenas, mas a coexistência,

Ou digamos que o fim precede o princípio,

E que o fim e o princípio estiveram sempre ali

Antes do princípio e depois do fim. (ELIOT, 1983)

O mover-se no tempo - mas um tempo diferente, transfigurado; o entre específico, que não é "nem de nem para"; o silêncio - falta de som, falha (de onde se parte e, afinal, aonde se quer regressar, pensando em regresso novamente como Pina) na fala; a imobilidade que não é repouso: são muitos os contatos entre Pina e Eliot e tantos outros. Ler "ponto morto" é, para mim, escutar Carlos de Oliveira: "Escreve-se sempre em ponto morto" - observa ele, em texto de $O$ aprendiz de feiticeiro -, "entre duas velocidades, a que se extinguiu e a que vai surgir" (OLIVEIRA, 1973, p. 195). Em outro ensaio, observo, a respeito desse poeta, que o ponto morto se dá justamente na fratura da velocidade, nos exatos lugar e instante entre. A locução "ponto morto" combina as noções de microlugar e morte para instaurar esse movimento - "mais subtil", na expressão do poema, "fingido", na descrição do texto d'O aprendiz de feiticeiro - e determinar o lugar exato do silêncio. É aí que se ouve melhor a poesia.

Um poeta leva a outro nesse capitonê que é, afinal, urdido por muito da modernidade poética. Aproximamnos aspectos daquilo a que chamo, em minhas pesquisas para o doutorado, de função deserto. Mas não vou mergulhar nisso. Os demais poetas vieram à página apenas na tentativa de tornar mais visíveis certos procedimentos de Pina, o sujeito, o tempo e o lugar de seu projeto literário. 


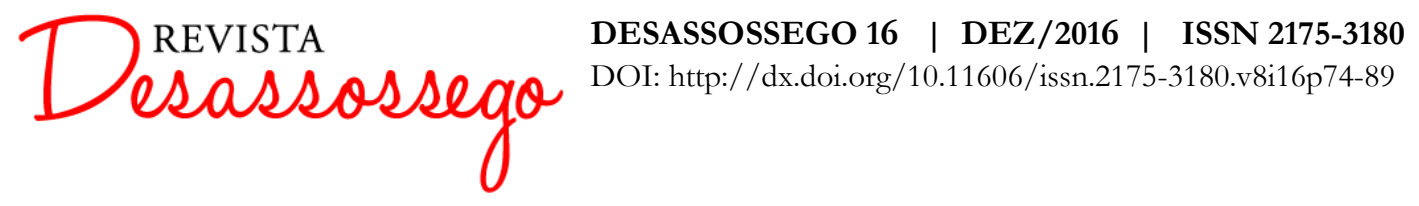

essa própria aproximação se mostra interessante para nós. É para aproveitá-la que citamos em segunda mão o autor francês:

"O deserto ainda não é o tempo nem o espaço, mas um espaço sem lugar e um tempo sem engendramento. Aí, apenas se pode errar, tempo sem passado, sem presente. Terra nua onde o homem nunca está presente, mas sempre fora. O deserto é esse fora onde não se pode permanecer, pois estar aí é sempre já estar fora”. (LEVY, 2011, p. 34)

Seguindo seu pensamento, Tatiana observa que "As palavras aqui estão sempre em suspenso, num tremor que não as deixa nunca no lugar”. E cita mais uma vez Blanchot: “Elas [as palavras] são de uma imobilidade mais movediça do que tudo que se move" (LEVY, 2011, p. 35). Esse deserto ou fora de que fala Banchot identifica-se com essa falta/falha/fala que é a poesia de Pina. É nesse, com esse e a respeito desse "nem tempo" e "nem espaço" que se faz sua escrita. Ai, nisso que também já caracterizamos como um entre atipico, vibram as palavras em sua imobilidade movediça. É como se passado, presente, futuro constituíssem linhas temporais a se mover a velocidades incoincidentes e não configurassem cruzamentos, mas sim feixes que permanecessem paralelos, mantendo as distâncias entre si. E justamente do não encontro dessas linhas (que, apesar disso, coexistem), resulta a falha que constitui a poesia. O mesmo ocorre com as linhas do espaço e também com as linhas subjetivas. Em outras palavras: é justamente na distância, no espaço/tempo outros inscritos na falha entre os feixes, que se configura a potência dessa escrita.

O fato de a ideia de regresso (outra das obsessões dessa poética) também girar sobre seus próprios gonzos passa a ser, agora, consequência previsível. Os fragmentos de poemas a seguir mostram o quanto esse regresso é coerente com as noções de tempo e (i)mobilidade em Pina, e põem em cena mais um descompasso: o do sujeito.

A visão de esse, de o que está de fora, de aquele que regressa sem ter partido dançando sobre os destroços da sua imagem, é o que me vê a mim; falo ainda de mim (PINA, 2013, p. 80)

o que regressa nunca saiu do mesmo sítio, e só esse regressa ao mesmo sítio, no limiar da sua Morte, encontrando todas as coisas no mesmo sítio e parando no princípio de tudo. 


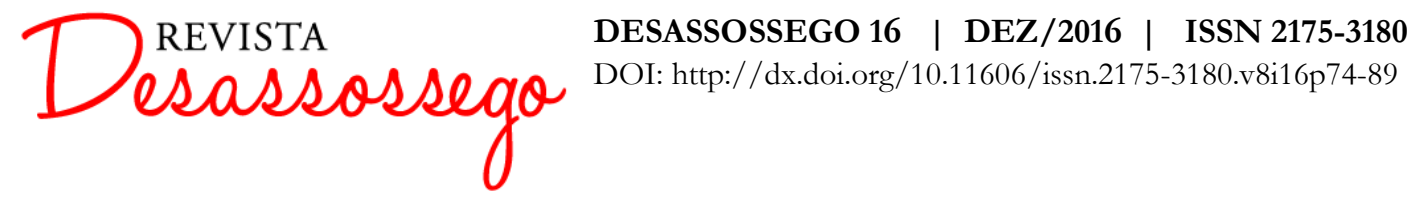

Para aqui chegar tive que percorrer tudo. ${ }^{11}$

A falta das palavras e do silêncio e da falta de isso é o que encontra seu começo e a sua memória e fala finalmente sobre todas as coisas. (PINA, 2013, p. 81)

Aquilo que está cada vez mais longe, a pura falta de coisa nenhuma, é o que Conhece e É a sua indizível inexistência.

Nós, os maus, onde é fora de fora de tudo, eternamente regressamos ao sítio de onde nunca saímos. (PINA, 2013, p. 86)

Estou cada vez mais longe de qualquer coisa, regressarei alguma vez a tudo o que há-de vir? O que está atrás de ti

é a tua imagem que o Futuro persegue. Este é um lado de tudo e o outro é o mesmo e o outro. (PINA, 2013, p. 87)

(O que regressa ao sítio de onde nunca saiu é o mesmo que nunca lá esteve, o que sobe a escada e transpõe a porta que dá para toda a parte). (PINA, 2013, p. 88)

As tensões acerca de uma subjetividade cindida e múltipla ${ }^{12}$ são constantemente repisadas, como em círculos obsessivos. Rosa Maria Martelo comenta essa desestabilização

\footnotetext{
11 Pode-se, também aqui, escutar Eliot: O que chamamos princípio é quase sempre o fim / E alcançar um fim é alcançar um princípio. / Fim é o lugar de onde partimos.” (ELIOT, 1981, p. 233) Também Tatiana Levy nos volta aos ouvidos: "A origem é o extremo que a arte pode esperar, e a exigência última da escrita é a de que o escritor retorne sobre ela"; mais adiante: "vale ressaltar que a origem, nesse contexto, não é sinônimo de começo, mas, ao contrário, aquilo a partir do que nada pode começar”. E, citando Blanchot: “"[a literatura] é a presença das coisas antes que o mundo o seja, a perseverança das coisas depois que o mundo desapareceu"' (LEVY, 2011, p. 33).

12 "Quem ficou aqui e onde, / e fala de isto agora?" (PINA, 2013, p. 104); "Estarei ainda muito perto da luz? / Poderei esquecer / estes rostos, estas vozes, / e ficar diante do meu rosto? // Às vezes, como num sonho, / vejo formas como um rosto / e pergunto: 'De quem é este rosto?' / E ainda: 'Quem pergunta isto?”' (PINA, 2013, p. 105). É o sonho, por sinal, uma das figurações mais recorrentes em Pina para essa subjetividade cindida e múltipla (veja-se, por exemplo, o poema "Luz", p. 322), atravessada por vozes de toda a história e tradição, ao ponto de não ser capaz de reconhecer o que, desse excesso, é o seu singular, voz alheia/voz própria, escritor/escritura.
} 


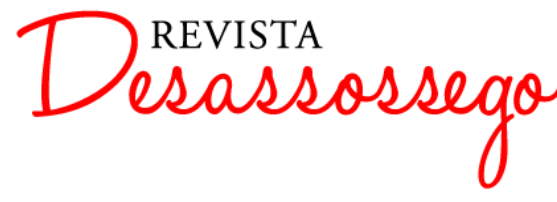

DESASSOSSEGO 16 | DEZ/2016 | ISSN 2175-3180

DOI: http://dx.doi.org/10.11606/issn.2175-3180.v8i16p74-89

da unidade do eu no artigo "Os Koans Revisitados (Ou de como Escrever entre Poesia e Prosa)":

Apoiado numa 'metodologia da dúvida' (Eiras 2002), Manuel António Pina é também um utilizador muito dubitativo do deíctico eu, que usa fazendo-o veicular uma elevada percentagem de vazio e incerteza. Os pontos de contacto com o esvaziamento da categoria do sujeito que os koans almejam produzir são muito visíveis em versos como estes: 'Também eu (isto) não tenho história / senão a de uma ausência / entre indiferença e indiferença' (Pina 2001: 253). (MARTELO, 2014, p. 15).

Rosa recupera um texto em que Pedro Eiras utiliza a expressão "metodologia da dúvida" ao se referir a Pina; Danilo Bueno, na revista Desassossego, também observa: "Onde começa o sujeito? Onde começa a escrita?. No limite da dúvida, decerto. Essa embaralhação das categorias em constante metamorfose aponta o caráter tenso da poesia pós-moderna, em que o simultâneo arquiteta perguntas mais importantes do que respostas" (BUENO, 2013, p. 126). A decisão (escolha poética, ou seja, a ética dessa escrita) pela indecidibilidade (acerca de sujeitos - memória ${ }^{13}$, identidade ${ }^{14}$, fala ${ }^{15}$, voz e rosto ${ }^{16}-$, de todo livro $^{17}$, de poema ${ }^{18}$, de palavra ${ }^{19}$ ) é aspecto fulcral para a poesia de Pina, e faz dela uma falta excessiva. Esta é justamente, retomando versos recém-citados, aquilo que "fala finalmente

\footnotetext{
${ }^{13}$ Leia-se "Numa estação de Metro", tão afim à poesia pessoana: “A minha juventude passou e eu não estava lá. / Pensava em outra coisa, olhava noutra direção. [...] Hoje, antigamente, ele tê-las-ia / amado de um amor imprudente e impudente, / como num sujo sonho adolescente / de que alguém, no outro dia, acordaria. // Pois tudo era memória, acontecia / há muitos anos, e quem se lembrava / era também memória que passava, / um rosto que entre os outros rostos se perdia. // Agora, vista daqui, da recordação, / a minha vida é uma multidão / onde, não sei quem, em vão procuro / o meu rosto, pétala dum ramo búmido, escuro." (PINA, 2013, p. 153) [grifo do autor]

14 "À minha volta estilhaça-se / o meu rosto em infinitos espelhos / e desmoronam-se os meus retratos nas molduras." (PINA, 2013, p. 162)

15 "Estou sempre a falar de mim ou não. O meu trabalho / é destruir, aos poucos, tudo o que me lembra. / Reflexão e, ao mesmo tempo, exercício mortal. / Normalmente regresso a casa tarde, doente. // Desta maneira (e doutras - / a carne é triste, hélas!, e eu já li tudo) / ocupo o lugar imóvel do poema. Procuro o sentido / (vivo ou morto!) para o liquidar. Mas onde? E como? E quem?” (PINA, 2013, p. 17)
}

17 No poema "Inquérito", interroga-se (e usamos "se", aqui, tomando-o como índice de indeterminação do sujeito, e não na função reflexiva do pronome): "Um dos dois mente, o escritor ou o livro, / acerca de qual deles escreve o outro. / Qual, ilegível, é Um? Qual é Mistério dividido? / Qual é espectro? Qual é corpo? // Que culpa inconclusa se oculta / na leitura, a do esquecimento ou a da loucura? / Que voz irresoluta aí murmura? / Que mesma voz outramente escuta? // 'E que eco ou evidência / fala na impossibilidade de falar? / Será prudente - perguntou ele - confiar / o Verdadeiro a tanta ausência?”' (PINA, 2013, p. 333)

${ }^{18}$ O poema "'Que dia? Que olhar?”" depois de retomar, em seu primeiro verso, o tema do caráter tardio do poeta moderno, problematiza o lido (pelo próprio poeta e por seus leitores) e o escrito, a identidade poética e a civil: "Cheguei demasiadamente tarde / e já todos se tinham ido embora, / restavam papéis velhos, vidas mortas, / identidade, sujidade, eternidade. // Comeram o meu corpo e / beberam o meu sangue; e, pelo caminho, a minha biblioteca / e escreveram a minha Obra Completa; / sobro, desapossado, eu." (PINA, 2013, p. 304.)

19 "É duro sonhar e ser o sonho, / falar e ser as palavras!" (PINA, 2013, p. 137). 


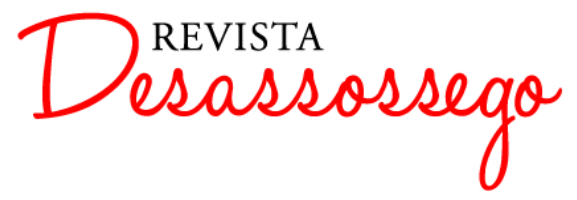

DESASSOSSEGO 16 | DEZ/2016 | ISSN 2175-3180

DOI: http://dx.doi.org/10.11606/issn.2175-3180.v8i16p74-89

sobre todas as coisas", "o que Conhece e É". Em vez de negativa, essa falta se faz positiva - ou, antes, multiplicadora: no lugar de se limitar a corresponder a um vazio pós-utopias, lutuoso por um esgotamento de sentidos na vida moderna, ela se abre a novas possibilidades. Portanto, é legítimo afirmar que a falta é fruto de excessos (daqueles tantos "tanto" que mencionamos no início deste texto) e, ao mesmo tempo, desejante e produtora de (outros) excessos. Nesse sentido, falta, em Pina, aproxima-se da noção de vaz̧io de Deleuze e Parnet: "Que confusão curiosa, a do vazio com a falta. [...] o deserto é um corpo sem órgãos que nunca foi contrário às tribos que o povoam, o vazio nunca foi contrário às partículas que nele se agitam.” (DELEUZE, PARNET, 1998, p. 106). Falta (que também é, como temos reiterado, falha/fala) constitui, acima de tudo, potência, muito mais do que exclusão.

O mais interessante de se observar, então, é como o status deslocado do sujeito, do tempo, do espaço e da linguagem, se não deixa de ser tematizado como um obstáculo, problema a ser penosamente enfrentado, configura-se também como o lugar próprio da poesia, constituindo, portanto (e paradoxalmente), a situação desejada. É apontando essas falhas e se assumindo como falta que a escrita de Pina se faz. Ou, de outra forma: a falta fala da falha (lugar), sobre a falha (assunto), e de maneira falha. É fundamentalmente de si mesma que trata essa poesia, e portanto ela é a própria argamassa: "falo ainda de mim", soa um dos versos já citados (em uso de primeira pessoa que, no singular ou no plural, marca todo o percurso da obra de Manuel António Pina, problematizado por oscilações com segunda e terceira pessoas e interrogações que ratificam a dúvida, ou indecisão, acerca de quem fala). Poesia que se assume nomeação imprópria, insuficiente - "As palavras não chegam, / a palavra ą̧ul não chega, / a palavra dor não chega.” (PINA, 2013, p. 232). Poema "A pura falta":

Tudo é sabido onde alguma coisa fala de si própria

e de falar de isso

e de falar de falar. (p. 86) ${ }^{20}$

\footnotetext{
${ }^{20}$ Recuperando Foucault, Tatiana Salem Levy escreve: “Aqui, no 'falo', na ficção moderna, o sujeito - o eu que fala - se fragmenta até desaparecer no vazio. [...] Distanciando-se da certeza daquele que fala, a literatura volta-se sobre si mesma, colocando em evidência seu próprio ser" (LEVY, 2011, p. 58). Assim, na modernidade a literatura não aponta mais nem para uma interioridade nem para algo que lhe seja exterior: "Como experiência do 'Falo', a obra moderna não se refere a algo exterior (nem a um objeto, nem a um sujeito), pois ela é seu próprio fora” (LEVY, 2011, p. 59).
} 


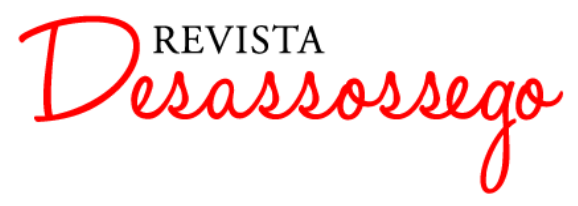

DESASSOSSEGO 16 | DEZ/2016 | ISSN 2175-3180

DOI: http://dx.doi.org/10.11606/issn.2175-3180.v8i16p74-89

Falar de si própria, falar de falar, falar de isso. Assim mesmo, de + isso, como mantém o poeta em toda a sua obra - ou de + isto; Pina usa a cada momento uma variação, e esse gesto é relevante, pois desloca do sintagma para a própria oscilação a função de dêitico: é a inconstância de isto/isso que significa, justamente ela indica a indecibilidade metamorfoseante de perto/longe, dentro/fora, eu/tu/outrem. A recusa da contração disso tira o status de substantivo do objeto da fala, para salientar um status outro - pronominal, no caso. Como se ao isso não correspondesse nenhum nome apropriado. Ele (isso) existe, e está próximo do emissor e/ou receptor, mas é inominável; ou: a fala falha ao se referir a isso, à falta - poderíamos escrever também que a fala falta ao se referir à falha.

Viemos insistindo na intercambialidade dos componentes do trinômio apenas para salientar o quanto da ênfase nessa poesia está muito mais na relação (o salto da linguagem, que permeia toda a frase sem se condensar em uma só palavra) do que em um significante ou outro; que ela se encontra no em potência (aquele entre não localizável em tempo ou espaço), e não nesta ou naquela linha ou outra espaço-temporal; que, afinal, essa poesia opta por essa indecidibilidade, na impossibilidade de eleger um só nome que corresponda ao seu dizer. Trata-se de um isto/isso que ouve vozes, sente tempos e vê lugares inúmeros, mas não se atém a nenhum deles.

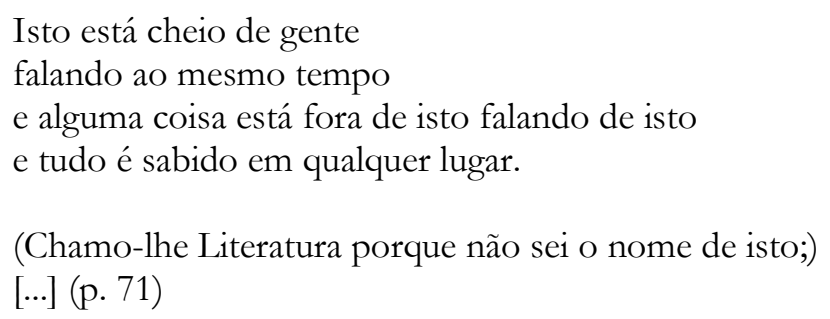

Com o verso "alguma coisa está fora de isto falando de isto" fresco na memória, lemos, em Tatiana Levy: "A literatura moderna se caracteriza, portanto, por esse desdobramento que lhe permite referir-se a si mesma sem nunca constituir uma interioridade, e sim uma passagem para o fora". Avançamos algumas páginas de Pina, e deparamos com dois poemas consecutivos, com os quais encerramos este artigo, mas não as reflexões acerca de Manuel António Pina. Os versos a seguir reiteram o que procuramos mostrar e trazem novas janelas a serem abertas futuramente (assim esperamos):

"Volto de novo ao princípio"

A ideia de isto cansa-me em qualquer sítio fora de qualquer sítio onde o meu cansaço é só um conceito. 


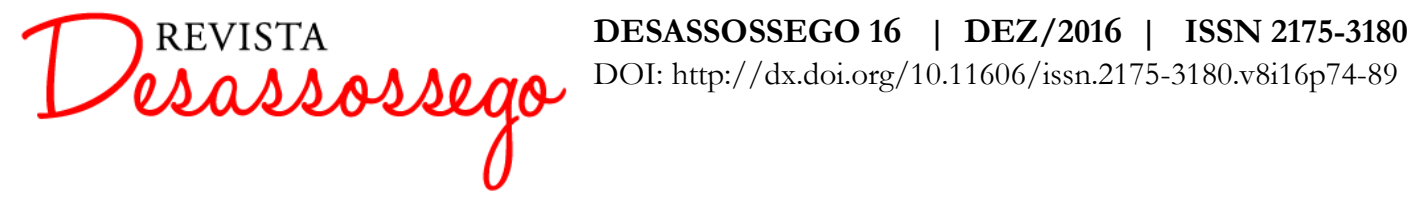

(Há qualquer coisa que quer falar e apenas foge;

as palavras perseguem a sua miragem,

e eu sou o lugar onde tudo isto se passa fora de mim,

a Literatura, o cansaço e a ideia de isso.

Já não tenho palavras para não dizer qualquer coisa.)

Volto de novo ao princípio de tudo, ao lado de fora, onde fala de isto;

o que aí falta está parado

sobre a Literatura. (p. 78)

"O que fala"

O grande movimento de tudo muda de sítio estando parado e isto não pode ser dito nem ficar calado.

Volto ao princípio de tudo, agora verdadeiramente só e Inocente.

É no centro de tudo

que fala de si próprio

e de isto (o que falta é

o que existe absolutamente).

Esta mão é todavia surpreendente

e subitamente fora de qualquer coisa

por onde se precipita e se agarra.

O meu desespero de súbito falta-me em isto. (p. 79)

\section{Bibliografia}

ALVES, Ida. "Conflito de opiniões na poesia portuguesa: o esterco lírico e o grito do anjo”. In: ALVES, Ida, PEDROSA, Celia (orgs.). Subjetividades em devir: estudos de poesia moderna e contemporânea. Rio de Janeiro: 7Letras, 2008. pp. 118-132.

ANDRADE, Carlos Drummond de. Alguma poesia. Rio de Janeiro: Record, 2001.

BELO, Ruy. Todos os poemas. $3^{\text {a }}$ ed. Lisboa: Assírio \& Alvim, 2009.

BRITTO, Paulo Henriques. Tarde. São Paulo: Companhia das Letras, 2007.

BUENO, Danilo. “'A literatura morreu': identidade, paradoxos e melancolia na poesia de Manuel António Pina”. Revista Desassossego, n. 10, dez 2013. p 121-130.

ELIOT, T.S. Poesia. Trad., introdução e notas Ivan Junqueira. Rio de Janeiro: Nova Fronteira, 1981. 


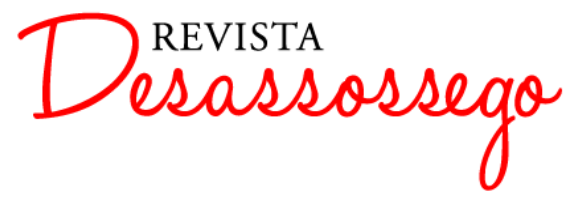

DESASSOSSEGO 16 | DEZ/2016 | ISSN 2175-3180

DOI: http://dx.doi.org/10.11606/issn.2175-3180.v8i16p74-89

- Quatro Quartetos. Trad. Maria Amélia Neto, $3^{\text {a }}$ ed. Lisboa: Ática, 1983.

ERTHAL, Aline Duque. "Deserto excessivo: povoamento de multiplicidades". Revista Texto Poético (ANPOLL), vol. 16, $1^{\circ}$ sem 2014. p. 9-30. Disponível em: http://www.revistatextopoetico.com.br/index.php/rtp/article/view/206/229

LEVY, Tatiana Salem. A experiência do fora: Blanchot, Foucault e Deleuze. Rio de Janeiro: Civilização Brasileira, 2011.

MARTELO, Rosa Maria. "Os Koans Revisitados (Ou de como Escrever entre Poesia e Prosa)". eLyra, n. 4, out. 2014. p. 7-20.

PINA, Manuel António. Todas as palavras: poesia reunida. Porto: Assírio \& Alvim, 2013.

QUEIRÓS, Luís Miguel. Entrevista a Manuel António Pina. Portal da Instituto de Literatura Comparada Margarida Losa. 18 ago. 2015. Disponível em: http://ilcml.com/blog/manuel-antonio-pina-entrevistado-por-luis-miguel-queiros-20112/. Acesso em: 22 jun. 2016. 